\title{
Chromogranin/secretogranin proteins in murine heart: myocardial production of chromogranin A fragment catestatin (Chga $364-384)$
}

\author{
Nilima Biswas • Erica Curello • Daniel T. O'Connor • \\ Sushil K. Mahata
}

Received: 27 August 2010 /Accepted: 10 September 2010 /Published online: 5 November 2010

(C) The Author(s) 2010. This article is published with open access at Springerlink.com.

\begin{abstract}
In the heart, the secretory granules containing the atrial natriuretic peptides (ANP) and B-type myocardial natriuretic peptide (BNP) provide the basis for the endocrine function of this organ. We sought to determine whether atrial and myocardial secretory granules contain chromogranin/ secretogranin proteins including chromogranin A (CHGA/ Chga), chromogranin B (CHGB/Chgb) and secretogranin II (SCG2/Scg2). Deconvolution microscopy on immunolabeled proteins revealed the presence of Chga, Chgb, and Scg2 in murine cardiac secretory granules. The presence of low plasma catestatin (CST: mChga $_{364-384}$ ) in older mice indicates diminished processing of Chga to CST with advancement of age, which is comparable to that found in humans. We have previously shown that CST $\left(\mathrm{hCHGA}_{352-372}\right)$ exerts potent cardio-suppressive effects on frog and rat heart, but the source of CST for such action has remained elusive. In
\end{abstract}

This work was supported by grants from the Department of Veterans Affairs (S.K.M.) and the National Institutes of Health (R01 DA011311 to S.K.M.; P01 HL58120 to S.K.M. and D.T.O.C.).

\footnotetext{
N. Biswas · E. Curello • D. T. O'Connor · S. K. Mahata $(\varangle)$ Department of Medicine (0838), UCSD School of Medicine and VASDHS,

9500 Gilman Drive,

La Jolla, CA 92093-0838, USA

e-mail:smahata@ucsd.edu

URL: http://medicine.ucsd.edu/hypertension

E. Curello · D. T. O'Connor

Molecular Genetics, University of California,

San Diego, CA, USA

E. Curello $\cdot$ D. T. O’Connor $\cdot$ S. K. Mahata

VA San Diego Healthcare System,

9500 Gilman Drive,

La Jolla, CA 92093-0838, USA
}

the present study, we found CST-related peptides in cardiomyocytes and in heart, which establishes an autocrine/paracrine function of CST in cardiac tissue. We conclude that cardiac secretory granules contain Chga, Chgb and Scg2 and that Chga is processed to CST in murine heart.

Keywords Chromogranin - Secretogranin · Catestatin . Heart · Cardiomyopathy $\cdot$ Mouse $(129 \mathrm{svJxC} 57 \mathrm{BL} / 6)$

\section{Introduction}

Despite advances in treatment, cardiovascular disease is still the leading cause of morbidity and mortality in the Western world. A prolonged cardiac hypertrophic state leads to heart failure and is commonly accompanied by complex changes in protein/ peptide levels in plasma and/or in the heart. Chromogranin A (human: CHGA; rodent: Chga), a 48- to 52-kDa acidic secretory protein in homeothermic vertebrates (Helle 2004; Montero-Hadjadje et al. 2008; Taupenot et al. 2003; Winkler and Fischer-Colbrie 1992), is a proprotein giving rise to several peptides of biological importance such as the dysglycemic hormone pancreastatin (PST) (Gayen et al. 2009; Sanchez-Margalet et al. 2010; Tatemoto et al. 1986), vasodilator and cardiosuppressive vasostatin (VST) (Aardal et al. 1993; Tota et al. 2008), antiadrenergic, antihypertensive and cardioinhibitory peptide catestatin (CST) (Angelone et al. 2008; Mahapatra et al. 2005; Mahata et al. 1997, 2000, 2010) and WE14 which acts as an autoantigen in type 1 diabetes (Stadinski et al. 2010). Although initially described in the chromaffin granules of the adrenal medulla, subsequent studies demonstrate widespread distribution of CHGA/Chga in endocrine tissues (Fischer-Colbrie et al. 1985; O'Connor 1983) and in the nervous system (Mahata et al. 1991; Somogyi et al. 1984). Using immunoelectron microscopy, 
Winkler's group elegantly demonstrated the presence of Chga and chromogranin $\mathrm{B}(\mathrm{Chgb})$ in the secretory granules in atrial myoendocrine cells of rat heart and their co-localization with atrial natriuretic peptide (ANP) (Steiner et al. 1990). Subsequently, in rat, Chga has been detected in Purkinje conduction fibers, in both atrium and ventricle, as well as in H9c2 cardiomyocytes (Weiergraber et al. 2000). A recent confocal microscopical study clearly shows co-localization of CHGA with B-type natriuretic peptide (BNP) in human ventricular myocytes of dilated and hypertrophic hearts (Pieroni et al. 2007).

The plasma concentration of CHGA is elevated in established human essential hypertension ( $\mathrm{O}^{\prime}$ Connor et al. 2008; Takiyyuddin et al. 1995) and in rodent model of genetic hypertension (O'Connor et al. 1999). Serum CHGA levels show distinct correlation with severity of cardiac dysfunction and act as a predictive factor for mortality in patients with chronic heart failure (Ceconi et al. 2002). Recent studies demonstrate a close and independent association between serum CHGA levels and outcome in patients with acute coronary syndromes (Estensen et al. 2006; Jansson et al. 2009; Omland et al. 2003) and in patients with acute (Dieplinger et al. 2009) and chronic (Ceconi et al. 2002) heart failure. ELISA assays with four different monoclonal antibodies show a significant amount of CHGA only in pathologic myocardium $(>0.05 \mu \mathrm{g} / \mathrm{g}$ of tissue) (Pieroni et al. 2007).

The circulating levels of CST decrease in patients with essential hypertension (O'Connor et al. 2002) and targeted ablation of the Chga gene in mice increases blood pressure, which can be "rescued" by replacement with CST (Mahapatra et al. 2005), indicating a direct role of CST in preventing hypertension. We have shown that in addition to its hypotensive action in rodents (Kennedy et al. 1998; Mahapatra et al. 2005) and in humans (Fung et al.), CST exerts cardiosuppressive effects on the isolated Langendorff-perfused rat heart under both basal and chemically stimulated conditions (Angelone et al. 2008). Thus, in addition to its important role in the control of blood pressure, CST is emerging as a peptide that has direct cardiovascular actions, suggesting that the negative inotropism and lusitropism of CST may be important components of its hypotensive action. In addition, we have recently found that plasma CHGA is elevated, and its processing to CST is diminished, in hypertension (O'Connor et al. 2008). Therefore, in the present study, we sought to determine the presence of chromogranin/ secretogranin proteins in murine heart and the processing of Chga to CST by using biochemical and mass spectrometry techniques. Our data reveal the presence of Chga, Chgb and Scg2 and several Chga-derived peptides containing CST motif in murine heart. In addition, processing of Chga to CST is diminished with advancing age.

\section{Materials and methods}

Tissue extraction Very young (10 days, 1-month old), young adult (2-month, 3-month-old) and adult (6-month-old) mice with mixed genetic background $(129 \mathrm{svJxC} 57 \mathrm{BL} / 6)$ were used in this study. Mice were kept in a 12-h dark/light cycle and were fed standard chow diet. Animal care and sacrifice were carried out according to the guidelines of Institutional Animal Care and utilization Committee. Heart and adrenal glands were collected from isoflurance-anesthetized mice and were freshly frozen in liquid nitrogen. Tissues were homogenized using a tissuemizer in TRIS-maleate buffer (10 mM TRIS-maleate, $\mathrm{pH} 7.0$, sucrose $0.2 \mathrm{M}$, EDTA $2 \mathrm{mM}$, Protease inhibitors cocktail and phosphatase inhibitors cocktail; Sigma, St. Louis, MO, USA), centrifuged at $8,000 \mathrm{~g}$ for $30 \mathrm{~min}$ and the supernatants were collected.

Cardiomyocyte culture and protein extraction Pups (34 days old) were sacrificed; heart tissues were collected in ADS buffer (HEPES sodium salt $20 \mathrm{mM}, \mathrm{NaCl} 116 \mathrm{mM}$, D-glucose $5.5 \mathrm{mM}, \mathrm{KCl} 5.4 \mathrm{mM}, \mathrm{Na}_{2} \mathrm{HPO}_{4} 9 \mathrm{mM}, \mathrm{MgSO}_{4}$ $0.4 \mathrm{mM})$ and digested with collagenase type II $(0.1 \mathrm{mg} / 100 \mathrm{ml}$ of ADS buffer; Worthington Biochemical). Cells were preplated for $1 \mathrm{~h}$ in uncoated plates to allow the fibroblasts to attach. The non-adhered cells were then plated in gelatincoated plates and cultured in DMEM-low glucose with $10 \%$ FBS and pen/strep for $48 \mathrm{~h}$. After that, medium was replaced by DMEM with $1 \%$ FBS and the cells were cultured for additional $24 \mathrm{~h}$. Spontaneously beating confluent monolayers were established $24-48 \mathrm{~h}$ after plating. At $72 \mathrm{~h}$, cells were washed with PBS twice, scrapped in lysis buffer $(20 \mathrm{mM}$ TRIS-Cl, pH 7.4, EDTA $1 \mathrm{mM}, \mathrm{NaCl} 75 \mathrm{mM}$, Triton X-100 $0.5 \%$, BME $0.1 \% \mathrm{v} / \mathrm{v})$. Cells were then centrifuged at $14,000 \mathrm{~g}$ for $10 \mathrm{~min}$ and the supernatants were collected.

Protein estimation Protein concentration was determined using Bio-Rad protein assay reagent (Bio-Rad laboratories, Hercules, CA, USA).

SDS-PAGE and immunoblot Proteins were separated using a $10 \%$ SDS-PAGE or a $10-20 \%$ Tricine gel (Novex precast gel; Invitrogen, San Diego, CA, USA) and processed for western blot analysis as described before (Biswas et al. 2008, 2009). We used rabbit polyclonal anti-human CST $(1: 3,000)$, goat polyclonal anti human CHGB (1:500, SC-1489; Santa Cruz Biotechnology, Santa Cruz, CA, USA), rabbit polyclonal ani-human SCG2 $(1: 1,000)$, and goat polyclonal anti-actin (1:500, SC-1615; Santa Cruz Biotechnology) for immunoblot studies.

Immunofluorescence Cardiomyocyte cultures were grown on coverslips for $72 \mathrm{~h}$, fixed with $2.5 \%$ paraformaldehyde and processed for immunocytochemistry as described before 
(Biswas et al. 2009). The primary antibodies used were: rabbit polyclonal anti-human CHGA (1:1,000 dilution), goat antiCHGB (1:100 dilution, SC-1489), rabbit anti-human SCG2 (1:2,000 dilution), goat anti-beta myosin heavy chain (MYH, $1: 100$, SC-12117) and goat anti-atrial natriuretic peptide (ANP, 1:100, SC-18811). Pictures were taken on a deltavision microscope as described before (Courel et al. 2008).

Purification of CST-containing peptides Frozen heart tissue (6-month-old animals) was extracted in $1 \mathrm{M}$ acetic acid, boiled for $5 \mathrm{~min}$, and homogenized. The supernatant (1 $\mathrm{mg}$ protein) was subjected to reverse phase HPLC purification (Symmetry C18 column, $5 \mu \mathrm{m}, 4.6 \times 250 \mathrm{~mm}$; Waters, Milford, MA, YSA). Proteins were eluted with a gradient $(25-60 \%$ over 15-85 $\mathrm{min}$ ) of acetonotrile at a flow rate of $0.5 \mathrm{ml} / \mathrm{min}$. Fractions (1 $\mathrm{min}$ ) were collected, lyophilized and spotted on a nitrocellulose membrane, and immunostained with a CSTspecific antibody. The CST-positive fractions from different run were lyophilized, pooled and subjected to mass spec analysis by electrospray method.

Anti-CST immunoprecipitation Frozen heart tissues (1-month-old animals) were homogenized in Tris-maleate buffer and the resulting supernatants were subjected to immunoprecipitation. Tissue extracts $(2 \mathrm{mg}$ and $1 \mathrm{mg}$ ) were pre-cleared by incubating with normal rabbit serum in $1 \times$ immunoprecipitation buffer (IP buffer: $10 \mathrm{mM}$ TRIS-Cl, pH 7.5, Triton X-100 0.1\%, NaCl $140 \mathrm{mM}$ ). Immunuoprecipitation was carried out overnight at $4{ }^{\circ} \mathrm{C}$ using polyclonal anti-human CST antibody. Antigen-antibody complexes were pulled out using protein $\mathrm{G}$ plus/protein A agarose (Calbiochem, San Diego, CA, USA) and washed 2 times with 1X IP buffer. The bound proteins were eluted from the beads either in Tricine loading dye for immunoblot analysis or with acetonitrile/water/TFA for mass spec analysis.

Mass spec analysis Electrospray and MALDI TOF analysis were carried out on a QTOF (QSTAR Elite) and Voyager DeSTR mass spectrometer respectively at the biomolecular and proteomics mass spectrometry facility, UCSD, department of Chemistry and Biochemistry as described before. The resulting peptide masses were analyzed in the program protein prospector (http://prospector.ucsf.edu) to identify the possible fragments and were listed.

CST EIA CST EIA was carried out using a CST specific EIA kit (EK-053-29) from Phoenix Pharmaceutical (Burlingame, CA, USA)

Statistical analysis Biochemical data are expressed as the mean \pm SEM. Multiple comparisons were made using oneway ANOVA followed by Bonferroni's post hoc test. Statistical significance was concluded at $p<0.05$.

\section{Results}

Expression of chromogranin/secretogranin proteins in murine heart and processing of Chga to CST in heart as compared to adrenal gland

To determine the expression of chromogranin/secretogranin proteins, primary culture of cardiomyocytes from 3- to 4day-old pups were analyzed by immunocytochemistry. Deconvolution microscopy shows punctuate staining of chromogranin/secretogranin proteins, which indicates discrete vesicular distribution of Chga (Fig. 1a), Chgb (Fig. 1b) and Scg2 (Fig. 1c) proteins in the cytoplasm of murine cardiomyocytes. As a positive control, we detected vesicular staining for the myocyte specific protein (MYH: $\sim 60 \%$ of cells) (Fig. 1d) and atrial natriuretic peptide (ANP: $\sim 4 \%$ of cells) (Fig. 1e). Cardiomyocyte cell extracts showed several distinct low molecular mass (ranging from 25 to $37 \mathrm{kDa}$ ) CST-positive fragments, along with low abundance full-length Chga (ran at $\sim 75 \mathrm{kDa}$ ) (Fig. 1f).

To identify CST-containing fragments, we carried out SDS-PAGE followed by CST immunoblot in heart and adrenal extracts. Adult heart extracts revealed three CSTpositive fragments with masses of $\sim 37, \sim 31$ and $\sim 15 \mathrm{kDa}$ (Fig. 1g). Murine heart also showed faint immunoreactivity at $\sim 75 \mathrm{kDa}$, which is the apparent migratory behavior of full-length Chga in SDS-PAGE gel. In addition, we detected a very high molecular mass form of Chga, possibly representing the proteoglycan form. Because of the presence of a high number of acidic amino acid residues within the primary structure of chromogranin/secretogranin proteins, these proteins run anomalously on SDS-PAGE and their apparent molecular weight differs from the weight deduced by primary amino acid sequence. In contrast to Chga, Chgb showed a major full-length form and also some low molecular mass fragments (Fig. 1g). Scg2, on the other hand, showed extensive aggregation or modification as evidenced by the presence of high molecular mass protein as major signal along with some low molecular mass fragments. Compared to the heart extract, the full-length Chga appeared to be highly prevalent in the adrenal extract; the major CST positive fragment ran at $75 \mathrm{kDa}$. After exposing the lower part of the membrane for a longer period of time, we detected comparable processing products of Chga between adrenal gland and heart as evidenced by the presence of smaller, processed forms of Chga with masses of $\sim 37, \sim 27$, and $\sim 15 \mathrm{kDa}$ in the adrenal extract (Fig. $1 \mathrm{~g}$ ). Although both the adrenal gland and heart express the processed forms, the ratio of processed to fulllength form is much higher in the heart compared to the adrenal gland indicating an extensive processing of Chga in the heart as compared to the adrenal gland. 

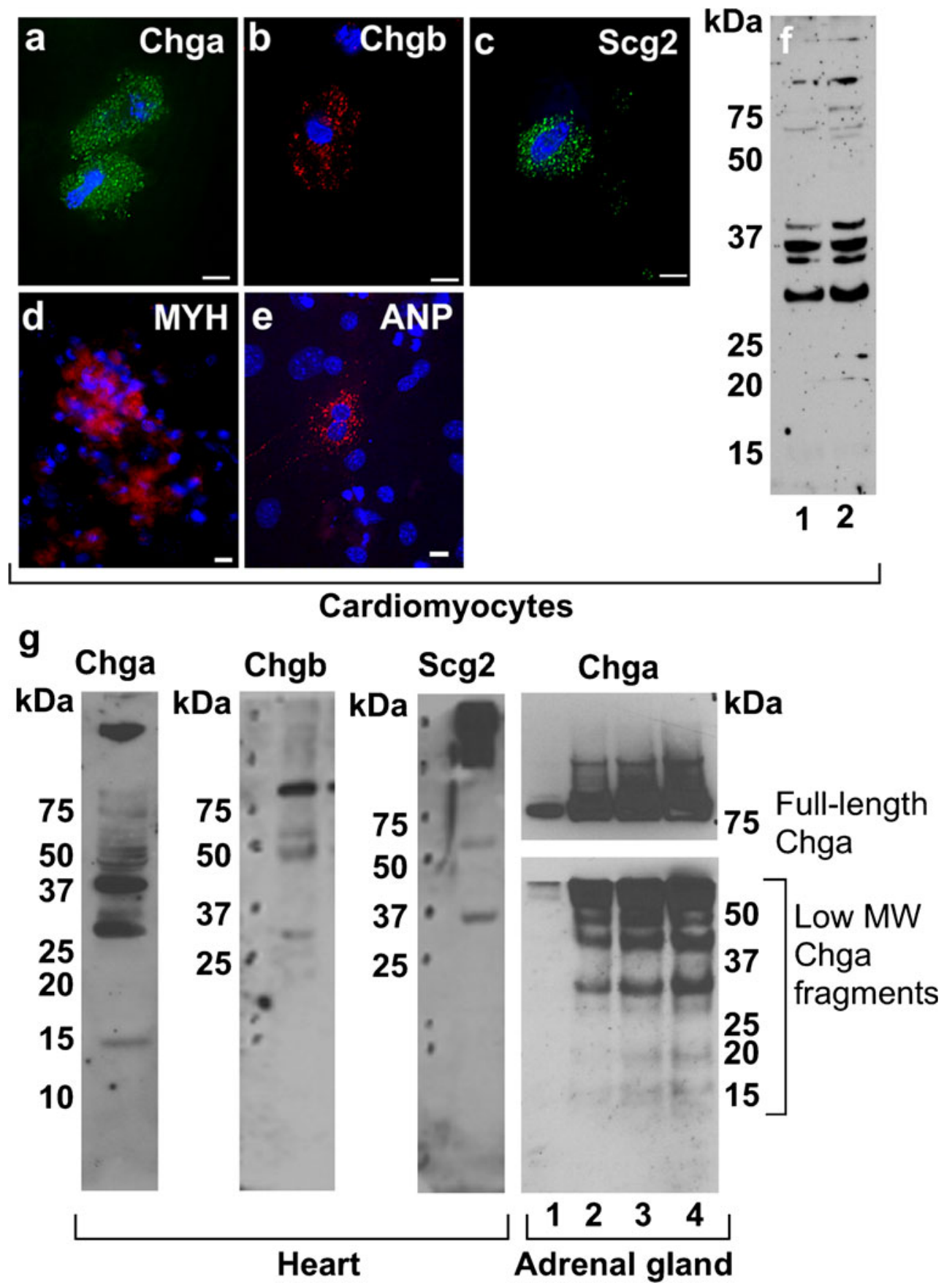

Fig. 1 The expression of chromogranin/secretogranin proteins in murine heart. The localization of Chga (a), Chgb (b) and Scg2 (c) were assessed in primary culture of cardiomyocytes, derived from 3- to 4-day-old pups. Cardiomyocytes were stained with primary antibodies specific for each chromogranin/secretogranin proteins and the cardiomyocyte specific markers such as myosin heavy chain $(\mathrm{MYH})$ (d) and atrial natriuretic peptide (ANP) (e). The secondary antibodies used were donkey anti-rabbit IgG-Alex Flur 488 (green fluorescence, 1:250) and donkey anti-goat IgG-Alex Flur 594 (red fluorescence, 1:350). Nuclei were visualized with Hoechst 33342 (blue). Cells were examined by deconvolution microscopy using a $\times 60$ objective (scale bar $5 \mu \mathrm{m}$ ) for the upper panel and a $\times 20$ objective (scale bar $10 \mu \mathrm{m})$ for the lower panel. f Cardiomyocyte cell extracts (lane $120 \mu \mathrm{g}$ protein and lane $240 \mu \mathrm{g}$ protein) were analyzed by SDS-PAGE followed by immunoblot with a CST specific antibody. g Freshly frozen adult (6-month-old) mice heart and adrenal tissues were homogenized in TRIS-maleate buffer and were subjected to SDS-PAGE and immunoblot analysis. Heart extracted proteins $(\sim 75 \mu \mathrm{g})$ were run by SDS-PAGE for the detection of Chga (by rabbit anti-human CST), Chgb (by goat anti-human CHGB) and Scg2 (by rabbit anti-human SCG2). Adrenal extracts (proteins in lane 1 $2 \mu \mathrm{g}$, lane $215 \mu \mathrm{g}$, lane $330 \mu \mathrm{g}$, and lane $460 \mu \mathrm{g}$ ) were also run by SDS-PAGE for the detection of Chga (by rabbit anti-human CST). For adrenal extract the full-length Chga signal was shown in the upper panel and the low molecular mass fragments were shown in the lower panel 
Age-dependent processing of Chga in murine heart

Although Chga is overexpressed in humans with essential hypertension and in genetic model of rodent hypertension, CST showed diminished expression in hypertensive subjects and in normotensive individuals with a family history positive for hypertension. Since hypertension is a late penetrating disease, and CST plays crucial roles in the development of hypertension, we sought to determine whether processing of Chga to CST in murine heart is altered with age. The full-length Chga signal (ran $\sim 75 \mathrm{kDa}$ ) as well as the intensity of the $\sim 37 \mathrm{kDa}$ Chga C-terminal fragment were increased in older animals (Fig. 2a). However, the intensity of a low molecular mass CST-specific peptide (less than $\sim 15 \mathrm{kDa}$ ) decreased in the
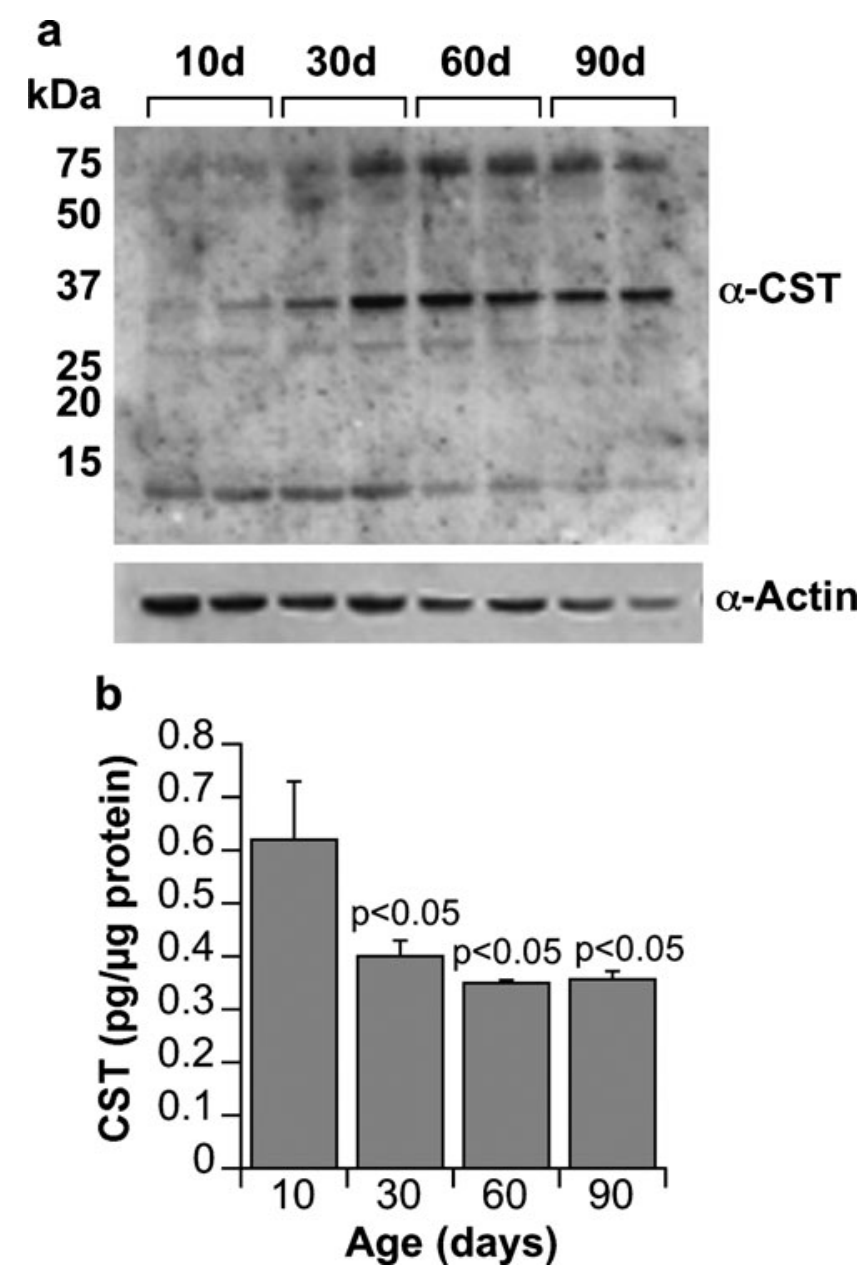

Fig. 2 Age-dependent processing of Chga to CST in murine heart. Heart from different age groups of mice (age in days: 10, 30, 60 and 90) were collected, homogenized and subjected to SDS-PAGE and immunoblot using a CST-specific antibody (rabbit anti-human CST) (a). b The endogenous CST concentrations were measured from tissue extracts using a CST EIA kit. CST concentrations are expressed in $\mathrm{pg} / \mu \mathrm{g}$ of protein heart of older animals (Fig. 2a). Consistent with immunoblot findings, CST EIA displayed a significant reduction of endogenous CST peptide in the heart extract of older mice (30-90 days old) as compared to younger (10-day-old) mice (Fig. 2b).

Identification of CST-containing peptides in adult mouse heart

Mouse heart extract was purified using the RP-HPLC column (Fig. 3) and the fractions collected for slot blot analysis. From the anti-CST slot blot, two fractions eluting at 48\% (61-63 $\mathrm{min})$ and 54\% (73-76 $\mathrm{min})$ acetonitrile were positive for CST immunoreactivity (Fig. 3b). To evaluate the apparent molecular mass of Chga C-terminal CSTcontaining fragments in these fractions, each fraction was lyophilized, pooled and subjected to mass spec analysis. Electrospray mass spec analysis revealed the presence of several CST-spanning peptides in heart extracts (Table 1). Among them, the peptides of mass 5,051.60 and 5,641.11, representing $\mathrm{Chga}_{356-398}$ and $\mathrm{Chga}_{357-404}$ or $\mathrm{Chga}_{358-405}$, respectively, had considerable overlap with the N-terminal part of the long CST sequence, $\mathrm{mChga}_{356-384}$. The peptides of mass 4,757.50, 5,244.85 and 2,478.34 contained a significant part of the N-terminal of short CST sequence, mChga $364-384$ (Table 1).

Immunoprecipitation of CST related peptides from young mouse heart

Since young animals showed more low molecular mass CST fragments $(<15 \mathrm{kDa}$; see Fig. 2a), we sought to purify CST related peptides from 1-month-old mice with an alternate strategy of immunoprecipitation. SDS-PAGE analysis (on a 10-20\% Tricine gel) of immunoprecipitated complex showed several fragments ranging from 20 to $150 \mathrm{kDa}$ (Fig. 4a, left panel). Besides these high molecular mass fragments, the longer exposure of the lower part of the membrane revealed the presence of a peptide that ran at $\sim 7 \mathrm{kDa}$ (Fig. $4 \mathrm{a}$, middle panel). As a positive control, we ran synthetic human CST (hCHGA $352-372$; Molecular mass $2.4 \mathrm{kDa}$ ) (Fig. 4a, right panel). Although we did not achieve a good separation between 2 and $7 \mathrm{kDa}$ protein even on a 10 $20 \%$ gel, our results indicate the presence of a low molecular mass (in the range of $2-7 \mathrm{kDa}$ ) fragment in the anti-CST immunoprecipitated complex. The MALDITOF analysis showed a major peptide of $\sim 11 \mathrm{kDa}$ corresponding to the C-terminal Chga derived fragment Chga $_{283-384}$ (Fig. 4b and Table 2). Several peptides with CST motif have been identified. Among them, peptides of mass 4,097 and 6,224 overlapped with the N-terminal sequence of short CST, mChga $364-384$ (Table 2). 
Fig. 3 Identification of CSTrelated peptides from heart extract. Mice hearts (6 months old) were homogenized in acetic acid and subjected to reverse phase HPLC purification. The proteins were eluted (the chromatogram showing protein elution as measured at $214 \mathrm{~nm}$ with time is shown in (a)), with a gradient of acetonitrile and the fractions were collected, lyophilized and spotted onto nitrocellulose membrane to probe with a CST-specific antibody (b). Fraction numbers are shown on the right of the respective slot blot (b)

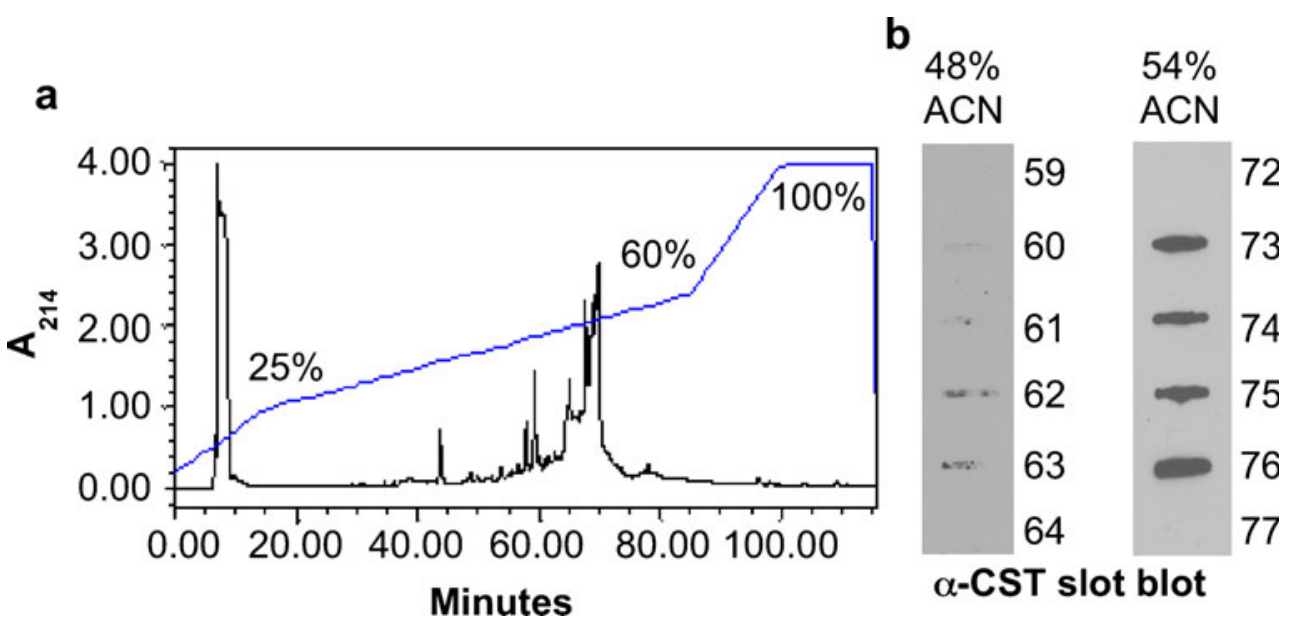

\section{Discussion}

Consistent with previous findings (Pieroni et al. 2007; Steiner et al. 1990; Weiergraber et al. 2000), we detected Chga and Chgb proteins in cardiomyocytes by deconvolution microscopy. Punctate staining patterns indicate vesicular storage of chromogranin/secretogranin proteins in cardiomyocytes in congruence with the elegant demonstration by Winkler's group using immunoelectron microscopy (Steiner et al. 1990). In addition to Chga and Chgb, we also found Scg2 in cardiomyocytes, which has not been shown before. A recent confocal microscopical study reveals colocalization of CHGA with BNP in human ventricular myocytes of dilated and hypertrophic hearts (Pieroni et al. 2007). CHGA has also been detected in Purkinje conduction fibers, in both atrium and ventricle, as well as in H9c2 cardiomyocytes (Weiergraber et al. 2000).

Tota's group was the first to demonstrate the cardiosuppressive effects of the N-terminal CHGA peptide VST on isolated and perfused heart preparations of eel, frog and rat, and to establish VST's direct involvement in the regulation of the contractile performance of hearts beating under basal
Table 1 Catestatin-related peptides detected by mass spectrometry from reverse phase HPLC purification of heart extract. The CST-immuno positive fractions from reverse phase HPLC, as detected by slot blot, were lyophilized, and subjected to electrospray mass spectrometry. The resulting peptides generated in the catestatin region are listed in bold

\begin{tabular}{|c|c|c|c|c|}
\hline $\begin{array}{l}\text { Mass (monoisotopic) } \\
\text { submitted }\end{array}$ & $\begin{array}{l}\text { Mass (monoisotopic) } \\
\text { matched }\end{array}$ & Sequence & Cleavage sites & \\
\hline \multirow[t]{2}{*}{$4,989.67$} & $4,989.37$ & $325-364$ & $\mathrm{E} / \mathrm{E}$ & $\mathrm{R} / \mathrm{S}$ \\
\hline & $4,989.54$ & $349-390$ & $\mathrm{~K} / \mathrm{E}$ & $\mathrm{P} / \mathrm{S}$ \\
\hline $5,148.74$ & $5,148.52$ & $328-369$ & $\mathrm{E} / \mathrm{E}$ & $\mathrm{S} / \mathrm{F}$ \\
\hline $5,057.51$ & $5,057.52$ & $339-380$ & $\mathrm{~K} / \mathrm{R}$ & $\mathrm{P} / \mathrm{G}$ \\
\hline $3,061.55$ & $3,061.50$ & $342-367$ & $\mathrm{~S} / \mathrm{R}$ & $\mathrm{K} / \mathrm{L}$ \\
\hline $4,341.31$ & $4,341.17$ & $344-380$ & $\mathrm{M} / \mathrm{D}$ & $\mathrm{P} / \mathrm{G}$ \\
\hline $3,034.66$ & $3,034.56$ & $346-371$ & $\mathrm{Q} / \mathrm{L}$ & $\mathrm{R} / \mathrm{T}$ \\
\hline $4,989.78$ & $4,989.54$ & $349-390$ & $\mathrm{~K} / \mathrm{E}$ & $\mathrm{P} / \mathrm{S}$ \\
\hline $5,051.6$ & $5,051.47$ & $356-398$ & $\mathbf{R} / \mathbf{L}$ & $\mathbf{E} / \mathbf{A}$ \\
\hline $5,641.11$ & $5,643.69$ & $357-404 / 358-405$ & $\mathbf{L} / \mathbf{E}$ or $\mathbf{E} / \mathbf{G}$ & E/E or $\mathbf{E} / \mathbf{G}$ \\
\hline $3,294.72$ & $3,294.67$ & $360-387$ & $\mathrm{E} / \mathrm{D}$ & $\mathrm{G} / \mathrm{W}$ \\
\hline $4,757.5$ & $4,751.41$ & $364-403$ & $\mathbf{D} / \mathbf{R}$ & $\mathbf{F} / \mathbf{E}$ \\
\hline $5,244.85$ & $5,244.63$ & $365-408$ & $\mathbf{R} / \mathbf{S}$ & $\mathbf{E} / \mathbf{E}$ \\
\hline $2,478.34$ & $2,478.36$ & $367-387$ & $\mathbf{M} / \mathbf{K}$ & G/W \\
\hline $1,754.94$ & $1,754.87$ & $369-383$ & $\mathrm{~L} / \mathrm{S}$ & $\mathrm{Q} / \mathrm{L}$ \\
\hline $2,676.45$ & $2,676.41$ & $369-390 / 370-391$ & $\mathrm{~S} / \mathrm{F}$ or $\mathrm{L} / \mathrm{S}$ & $\mathrm{S} / \mathrm{S}$ or $\mathrm{P} / \mathrm{S}$ \\
\hline $5,187.64$ & $5,187.51$ & $369-412$ & $\mathrm{~L} / \mathrm{S}$ & $\mathrm{S} / \mathrm{A}$ \\
\hline $2,369.22$ & $2,369.2$ & $376-395$ & $\mathrm{Y} / \mathrm{G}$ & $\mathrm{D} / \mathrm{S}$ \\
\hline $3,828.98$ & $3,828.88$ & $378-409$ & $\mathrm{~F} / \mathrm{R}$ & $\mathrm{E} / \mathrm{E}$ \\
\hline $2,008.99$ & $2,009.00$ & $379-395$ & $\mathrm{R} / \mathrm{D}$ & $\mathrm{D} / \mathrm{S}$ \\
\hline
\end{tabular}

Mouse catestatin sequence:

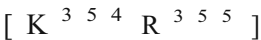

LEGEDDPDR ${ }^{364}$ SMKLSFR TRAYGFRDPGPQL $\left[\mathrm{R}^{385} \mathrm{R}^{386}\right]$

Long CST: Chea $_{356-384}$

Short CST: mChga $364-384$ 
a
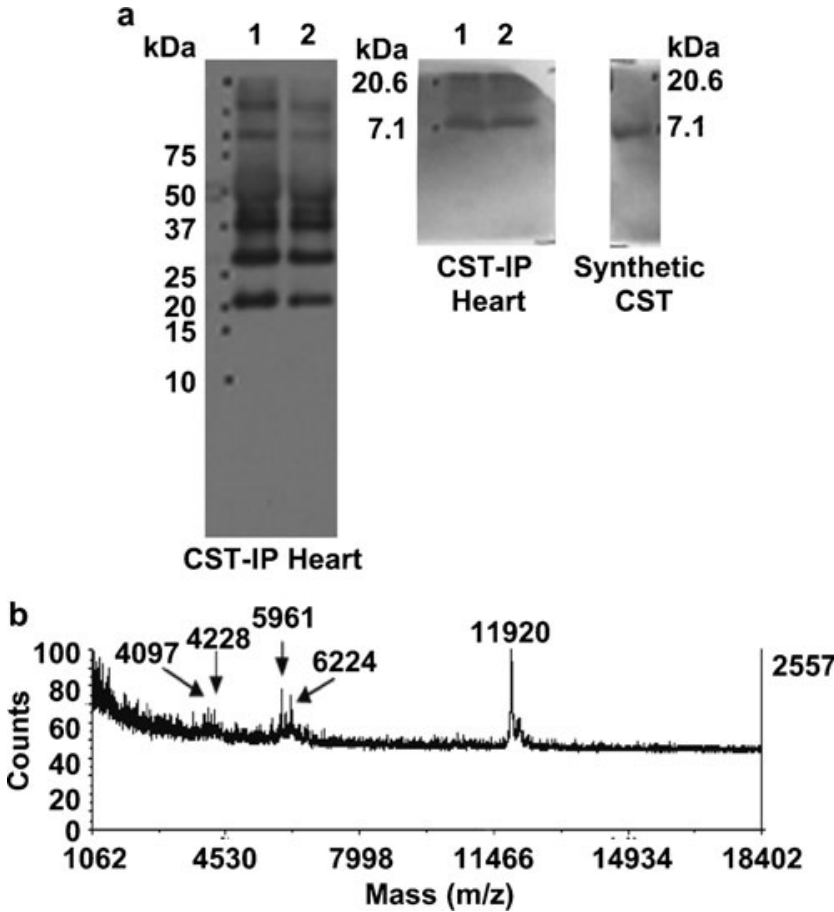

Fig. 4 Anti-CST immunoprecipitation from the heart extract. Mice heart (1-month-old animal) were homogenized in TRIS-maleate buffer and subjected to immunoprecipitation from 2 to $1 \mathrm{mg}$ protein with anti-CST antibody. The antigen-antibody complexes were pulled down with Protein $\mathrm{A} / \mathrm{G}$ beads and subjected to immunoblot analysis (lane 1 IP from $2 \mathrm{mg}$ protein, lane $2 \mathrm{IP}$ from $1 \mathrm{mg}$ protein) (a). In (a), rabbit anti-human CST antibody was used to detect CST-related peptides. The middle panel of (a) showed the darker exposure of the lower part of the gel. The right panel of (a) showed the running position of the synthetic human CST in the same gel. For MALDI-TOF (b), proteins eluted from the beads with acetonitrile/water/TFA were lyophilized and analyzed by mass spec

(i.e., non-stimulated) as well as stimulated (e.g., isoproterenol) conditions (Cerra et al. 2004, 2006; Imbrogno et al. 2004; Tota et al. 2003). In subsequent studies, they have detected natural VST-containing peptides in rat heart (Glattard et al. 2006), which basically established an autocrine/paracrine regulation of cardiac function by VST. We have recently demonstrated that, like VST, CST also induces cardio-suppressive effects in frog and rat heart (Angelone et al. 2008; Mazza et al. 2008). Therefore, it was crucial to demonstrate that CST-containing peptides are in fact generated in the heart. The present studies clearly show that CST-containing peptides are indeed generated in murine heart, which establishes an autocrine/paracrine action of CST in cardiac function. Immunoprecipitation of heart extracts with CST followed by immunoblots confirms generation of CST peptide in heart. In fact, we have previously shown that CST inhibits catecholamine secretion through an autocrine/paracrine mechanism (Mahata et al. 1997). It is interesting to note that heart extracts or cardiomyocytes contain very little amount full-length Chga as opposed to adrenal gland where the major band represents the full-length Chga, which is consistent with the findings that catecholamines inhibit proteolytic processing of Chga in the adrenal medulla (Wolkersdorfer et al. 1996). The high molecular weight bands detected for Chga and Scg2 possibly represent the proteoglycan form of these proteins. Of note, the proteoglycan form for Chgb is undetectable in murine heart.

It appears that processing of Chga to CST is diminished in heart with advancing age as judged by low CST. This is particularly relevant in context of hypertension, which is a late-penetrating disease where CST plays a crucial role. We have previously shown that CST (low) is inversely proportional to CHGA (high) in hypertensive human subjects, for which we have implicated a diminished processing of CHGA to CST (O'Connor et al. 2008). In this context, it should be mentioned that CHGA has been shown to increase in proportion to severity of cardiac dysfunction and to be associated with prognosis in patients with both chronic and post-infarction heart failure (Ceconi et al. 2002; Omland et al. 2003). In addition, it has been shown recently that plasma CHGA levels obtained within the first $24 \mathrm{~h}$ of admission are independently associated with the incidence of death in patients with acute coronary syndromes (Jansson et al. 2009).

In conclusion, we have detected chromogranin/secretogranin proteins including Chga, Chgb and $\mathrm{Scg} 2$ in murine heart where Chga is processed to CST-related peptides, implicating an autocrine/paracrine regulation of cardiac function by CST.
Table 2 Catestatin spanning peptides detected by mass spectrometry from immunoprecipitation of heart extract. Heart extract was subjected to immunoprecipitation with a CST-specific antibody. Proteins were eluted from the beads with acetonitrile/water/TFA, lyophilized and analyzed by MALDI-TOF. The detected peptides are summarized below

\begin{tabular}{lcc}
\hline Mass (average) submitted & Mass (average) matched & Sequence \\
\hline 4,097 & $4,097.65$ & $339-372 / 340-373$ \\
& $4,098.62$ & $365-399$ \\
4,228 & $4,225.82$ & $338-372$ \\
5,733 & $5,736.46$ & $331-377$ \\
& $5,738.53$ & $342-389$ \\
5,961 & $5,961.67$ & $333-381$ \\
6,224 & $6,218.86$ & $365-417$ \\
11,920 & $11,920.02$ & $283-384$ \\
\hline
\end{tabular}


Acknowledgments We are grateful to Professor Elizabeth A. Komives (Department of Chemistry and Biochemistry, University of California, San Diego) for helping us with mass spec analysis. We are thankful to UCSD School of Medicine light microscopy facility (specialized support grant P30 CA23100).

Disclosure statement The authors have nothing to disclose.

Open Access This article is distributed under the terms of the Creative Commons Attribution Noncommercial License which permits any noncommercial use, distribution, and reproduction in any medium, provided the original author(s) and source are credited.

\section{References}

Aardal S, Helle KB, Elsayed S, Reed RK, Serck-Hanssen G (1993) Vasostatins, comprising the N-terminal domain of chromogranin A, suppress tension in isolated human blood vessel segments. J Neuroendocrinol 5:405-412

Angelone T, Quintieri AM, Brar BK, Limchaiyawat PT, Tota B, Mahata SK, Cerra MC (2008) The antihypertensive chromogranin A peptide catestatin acts as a novel endocrine/paracrine modulator of cardiac inotropism and lusitropism. Endocrinology 149:4780-4793

Biswas N, Vaingankar SM, Mahata M, Das M, Gayen JR, Taupenot L, Torpey JW, O'Connor DT, Mahata SK (2008) Proteolytic cleavage of human chromogranin A containing naturally occurring catestatin variants: differential processing at catestatin region by plasmin. Endocrinology 149:749-757

Biswas N, Rodriguez-Flores JL, Courel M, Gayen JR, Vaingankar SM, Mahata M, Torpey JW, Taupenot L, O'Connor DT, Mahata SK (2009) Cathepsin L Co-localizes with chromogranin A in chromaffin vesicles to generate active peptides. Endocrinology 150:3547-3557

Ceconi C, Ferrari R, Bachetti T, Opasich C, Volterrani M, Colombo B, Parrinello G, Corti A (2002) Chromogranin A in heart failure; a novel neurohumoral factor and a predictor for mortality. Eur Heart J 23:967-974

Cerra MC, De Iuri L, Angelone T, Corti A, Tota B (2006) Recombinant N-terminal fragments of chromogranin-A modulate cardiac function of the Langendorff-perfused rat heart. Basic Res Cardiol 101:43-52

Corti A, Mannarino C, Mazza R, Angelone T, Longhi R, Tota B (2004) Chromogranin A N-terminal fragments vasostatin-1 and the synthetic CGA 7-57 peptide act as cardiostatins on the isolated working frog heart. Gen Comp Endocrinol 136:217-224

Courel M, Vasquez MS, Hook VY, Mahata SK, Taupenot L (2008) Sorting of the neuroendocrine secretory protein Secretogranin II into the regulated secretory pathway: role of $\mathrm{N}$ - and C-terminal alpha-helical domains. J Biol Chem 283:11807-11822

Dieplinger B, Gegenhuber A, Struck J, Poelz W, Langsteger W, Haltmayer M, Mueller T (2009) Chromogranin A and Cterminal endothelin-1 precursor fragment add independent prognostic information to amino-terminal proBNP in patients with acute destabilized heart failure. Clin Chim Acta 400:91-96

Estensen ME, Hognestad A, Syversen U, Squire I, Ng L, Kjekshus J, Dickstein K, Omland T (2006) Prognostic value of plasma chromogranin A levels in patients with complicated myocardial infarction. Am Heart J 152(927):e921-926
Fischer-Colbrie R, Lassmann H, Hagn C, Winkler H (1985) Immunological studies on the distribution of chromogranin $\mathrm{A}$ and $\mathrm{B}$ in endocrine and nervous tissues. Neuroscience 16:547-555

Fung MM, Salem RM, Mehtani P, Thomas B, Lu CF, Perez B, Rao F, Stridsberg M, Ziegler MG, Mahata SK, O'Connor DT Direct vasoactive effects of the chromogranin A (CHGA) peptide catestatin in humans in vivo. Clin Exp Hypertens 32:278-287

Gayen JR, Saberi M, Schenk S, Biswas N, Vaingankar SM, Cheung WW, Najjar SM, O’Connor DT, Bandyopadhyay G, Mahata SK (2009) A novel pathway of insulin sensitivity in chromogranin a null mice: A crucial role for pancreastatin in glucose homeostasis. J Biol Chem 284:28498-28509

Glattard E, Angelone T, Strub JM, Corti A, Aunis D, Tota B, Metz-Boutigue MH, Goumon Y (2006) Characterization of natural vasostatin-containing peptides in rat heart. FEBS J 273:3311-3321

Helle KB (2004) The granin family of uniquely acidic proteins of the diffuse neuroendocrine system: comparative and functional aspects. Biol Rev Camb Philos Soc 79:769-794

Imbrogno S, Angelone T, Corti A, Adamo C, Helle KB, Tota B (2004) Influence of vasostatins, the chromogranin A-derived peptides, on the working heart of the eel (Anguilla anguilla): negative inotropy and mechanism of action. Gen Comp Endocrinol 139:20-28

Jansson AM, Rosjo H, Omland T, Karlsson T, Hartford M, Flyvbjerg A, Caidahl K (2009) Prognostic value of circulating chromogranin A levels in acute coronary syndromes. Eur Heart $\mathrm{J}$ 30:25-32

Kennedy BP, Mahata SK, O'Connor DT, Ziegler MG (1998) Mechanism of cardiovascular actions of the chromogranin A fragment catestatin in vivo. Peptides 19:1241-1248

Mahapatra NR, O'Connor DT, Vaingankar SM, Sinha Hikim AP, Mahata M, Ray S, Staite E, Wu H, Gu Y, Dalton N, Kennedy BP, Ziegler MG, Ross J Jr, Mahata SK (2005) Hypertension from targeted ablation of chromogranin A can be rescued by the human ortholog. J Clin Invest 115:1942-1952

Mahata SK, Mahata M, Marksteiner J, Sperk G, Fischer-Colbrie R, Winkler H (1991) Distribution of mRNAs for chromogranins A and B and secretogranin II in rat brain. Eur J Neurosci 3:895-904

Mahata SK, O'Connor DT, Mahata M, Yoo SH, Taupenot L, Wu H, Gill BM, Parmer RJ (1997) Novel autocrine feedback control of catecholamine release. A discrete chromogranin A fragment is a noncompetitive nicotinic cholinergic antagonist. J Clin Invest 100:1623-1633

Mahata SK, Mahata M, Wakade AR, O'Connor DT (2000) Primary structure and function of the catecholamine release inhibitory peptide catestatin (chromogranin A344-364): Identification of amino acid residues crucial for activity. Mol Endocrinol 14:1525-1535

Mahata SK, Mahata M, Fung MM, O'Connor DT (2010) Catestatin: a multifunctional peptide from chromogranin A. Regul Pept $162: 33-43$

Mazza R, Gattuso A, Mannarino C, Brar BK, Barbieri SF, Tota B, Mahata SK (2008) Catestatin (chromogranin A344-364) is a novel cardiosuppressive agent: inhibition of isoproterenol and endothelin signaling in the frog heart. Am J Physiol Heart Circ Physiol 295:H113-122

Montero-Hadjadje M, Vaingankar S, Elias S, Tostivint H, Mahata SK, Anouar Y (2008) Chromogranins A and B and secretogranin II: evolutionary and functional aspects. Acta Physiol (Oxf) 192:309-324

O'Connor DT (1983) Chromogranin: widespread immunoreactivity in polypeptide hormone producing tissues and in serum. Regul Pept 6:263-280

O'Connor DT, Takiyyuddin MA, Printz MP, Dinh TQ, Barbosa JA, Rozansky DJ, Mahata SK, Wu H, Kennedy BP, Ziegler MG, 
Wright FA, Schlager G, Parmer RJ (1999) Catecholamine storage vesicle protein expression in genetic hypertension. Blood Press 8:285-295

O'Connor DT, Kailasam MT, Kennedy BP, Ziegler MG, Yanaihara N, Parmer RJ (2002) Early decline in the catecholamine releaseinhibitory peptide catestatin in humans at genetic risk of hypertension. J Hypertens 20:1335-1345

O'Connor DT, Zhu G, Rao F, Taupenot L, Fung MM, Das M, Mahata SK, Mahata M, Wang L, Zhang K, Greenwood TA, Shih PA, Cockburn MG, Ziegler MG, Stridsberg M, Martin NG, Whitfield JB (2008) Heritability and genome-wide linkage in US and australian twins identify novel genomic regions controlling chromogranin a: implications for secretion and blood pressure. Circulation 118:247-257

Omland T, Dickstein K, Syversen U (2003) Association between plasma chromogranin A concentration and long-term mortality after myocardial infarction. Am J Med 114:25-30

Pieroni M, Corti A, Tota B, Curnis F, Angelone T, Colombo B, Cerra MC, Bellocci F, Crea F, Maseri A (2007) Myocardial production of chromogranin A in human heart: a new regulatory peptide of cardiac function. Eur Heart J 28:1117-1127

Sanchez-Margalet V, Gonzalez-Yanes C, Najib S, Santos-Alvarez J (2010) Metabolic effects and mechanism of action of the chromogranin Aderived peptide pancreastatin. Regul Pept 161:8-14

Somogyi P, Hodgson AJ, DePotter RW, Fischer-Colbrie R, Schober M, Winkler H, Chubb IW (1984) Chromogranin immunoreactivity in the central nervous system. Immunochemical characterisation, distribution and relationship to catecholamine and enkephalin pathways. Brain Res 320:193-230

Stadinski BD, Delong T, Reisdorph N, Reisdorph R, Powell R, Armstrong M, Piganelli J, Barbour G, Bradley B, Crawford F, Marrack P, Mahata SK, Kappler JW, Haskins K (2010) Chromogranin A is an autoantigen in type 1 diabetes. Nat Immunol 11:225-231
Steiner HJ, Weiler R, Ludescher C, Schmid KW, Winkler H (1990) Chromogranins $\mathrm{A}$ and $\mathrm{B}$ are co-localized with atrial natriuretic peptides in secretory granules of rat heart. J Histochem Cytochem 38:845-850

Takiyyuddin MA, Parmer RJ, Kailasam MT, Cervenka JH, Kennedy B, Ziegler MG, Lin MC, Li J, Grim CE, Wright FA et al (1995) Chromogranin A in human hypertension. Influence of heredity. Hypertension 26:213-220

Tatemoto K, Efendic S, Mutt V, Makk G, Feistner GJ, Barchas JD (1986) Pancreastatin, a novel pancreatic peptide that inhibits insulin secretion. Nature 324:476-478

Taupenot L, Harper KL, O'Connor DT (2003) Mechanisms of disease: the chromogranin-secretogranin family. New Engl J Med 348:1134-1149

Tota B, Mazza R, Angelone T, Nullans G, Metz-Boutigue MH, Aunis D, Helle KB (2003) Peptides from the N-terminal domain of chromogranin A (vasostatins) exert negative inotropic effects in the isolated frog heart. Regul Pept 114:91-99

Tota B, Angelone T, Mazza R, Cerra MC (2008) The chromogranin A-derived vasostatins: new players in the endocrine heart. Curr Med Chem 15:1444-1451

Weiergraber M, Pereverzev A, Vajna R, Henry M, Schramm M, Nastainczyk W, Grabsch H, Schneider T (2000) Immunodetection of alpha1E voltage-gated $\mathrm{Ca}(2+)$ channel in chromograninpositive muscle cells of rat heart, and in distal tubules of human kidney. J Histochem Cytochem 48:807-819

Winkler H, Fischer-Colbrie R (1992) The chromogranins A and B: the first 25 years and future perspectives. Neuroscience 49:497-528

Wolkersdorfer M, Laslop A, Lazure C, Fischer-Colbrie R, Winkler H (1996) Processing of chromogranins in chromaffin cell culture: effects of reserpine and alpha-methyl-p-tyrosine. Biochem J 316:953-958 